Louisiana State University

LSU Digital Commons

Faculty Publications

Department of Biological Sciences

8-1-2016

\title{
A Framework for Implementing Course-Based Undergraduate Research Experiences (CUREs) in Freshman Biology Labs
}

Arundhati Bakshi

Louisiana State University

Lorelei E. Patrick

Louisiana State University

E. William Wischusen

Louisiana State University

Follow this and additional works at: https://digitalcommons.Isu.edu/biosci_pubs

\section{Recommended Citation}

Bakshi, A., Patrick, L., \& Wischusen, E. (2016). A Framework for Implementing Course-Based

Undergraduate Research Experiences (CUREs) in Freshman Biology Labs. American Biology Teacher, 78 (6), 448-455. https://doi.org/10.1525/abt.2016.78.6.448

This Article is brought to you for free and open access by the Department of Biological Sciences at LSU Digital Commons. It has been accepted for inclusion in Faculty Publications by an authorized administrator of LSU Digital Commons. For more information, please contact ir@lsu.edu. 


\section{FEATURE ARTICLE}

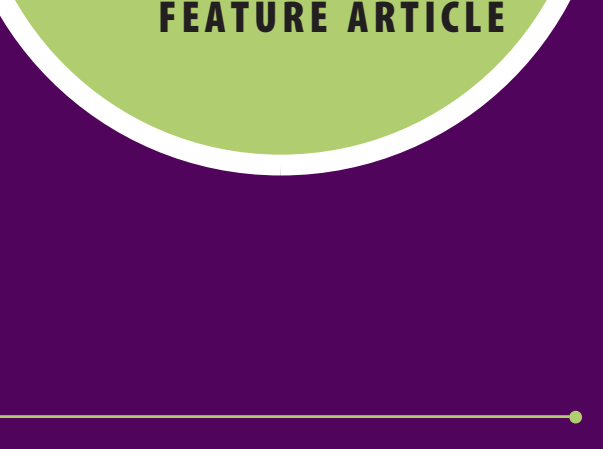

A Framework for Implementing Course-Based Undergraduate Research Experiences (CUREs) in Freshman Biology Labs

- ARUNDhATI BAKSHI, LORELEI E. PATRICK,

E. WILLIAM WISCHUSEN

\section{Abstract}

There have been many calls to make research experiences available to more undergraduate students. One way to do this is to provide course-based undergraduate research experiences (CUREs), but providing these on a scale large enough to accommodate many students can be a daunting undertaking. Indeed, other researchers have identified time to develop materials and course size as significant barriers to widespread implementation of CUREs. Based on our own experiences implementing CUREs at a large research university, we present a flexible framework that we have adapted to multiple research projects, share class materials and rubrics we have developed, and suggest logistical strategies to lower these implementation barriers.

Key Words: Authentic research experiences; undergraduates; research; graduate teaching assistants; freshman biology lab; course-based undergraduate research experience; CURE.

\section{$\bigcirc$ Background}

For more than a decade, there have been calls to increase undergraduate exposure to research experiences (AAAS, 2011; Graham et al., 2013). Many studies have shown that authentic research experiences help aspiring scientists better understand and practice science (e.g., Lopatto, 2004, 2007; Brownell et al., 2012, 2015; Linn et al., 2015). Undergraduate research experiences are typically split into (1) the traditional, structured research experiences that happen in a principal investigator's (PI's) lab over one or more semesters (hereafter "UREs" - undergraduate research experiences); and (2) intensive summer research experiences, during which students fully engage in research for numerous weeks in the summer (hereafter "SUREs" - summer undergraduate research experiences). While UREs and SUREs have been organized and funded by many universities and funding agencies for decades, they are necessarily limited in the number of students that can participate - both by the size of the typical research lab and the number of students a PI can reasonably mentor - making these positions few, selective, and competitive (Linn et al., 2015). Furthermore, SUREs require students to be available full-time over the summer, and mentors (graduate students or PIs) to invest time and effort beyond their regular commitments. While generous stipends can secure student availability, they also make SUREs expensive to operate (Lei \& Chuang, 2009). Course-based undergraduate research experiences (CUREs) are relatively new compared to UREs and SUREs and have the advantage of allowing a comparatively large number of students to gain research experience by moving research from a research laboratory to a teaching laboratory as part of a required or elective course (Linn et al., 2015). This eliminates the need for out-of-class time commitment on the part of both students and mentors, as well as the expense of a stipend since students earn course credit for their participation (Lei \& Chuang, 2009). CUREs can also allow a greater number of lower-division students to gain research experience than do typical UREs or SUREs, which tend to favor upperclassmen (Linn et al., 2015).

Despite these advantages, implementation and scalability of CUREs have been limited thus far; most CUREs that we have encountered in the literature have served $<100$ students per semester (e.g., Miller et al., 2013; Russell et al., 2015). Recent work has uncovered several barriers faced by faculty and departments when implementing CUREs (Spell et al., 2014) - the most important across all institution types being lack of time for faculty to develop in-class research experiences. Among other important barriers faced by nearly all institutional types were class size, number of sections, and cost of implementation (Spell et al., 2014). To lower the barriers preventing CURE implementation, Spell et al.

The American Biology Teacher, Vol. 78, No 6, paģes. 448-455, ISSN 0002-7685, electronic ISSN 1938-4211. (C) 2016 National Association of Biology Teachers. All rights

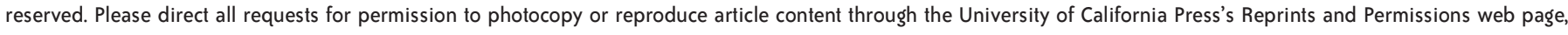
www.ucpress.edu/journals.php?p=reprints. DOI: 10.1525/abt.2016.78.6.448. 
(2014) suggested expanding grant supplements to fund CUREs, partnering with education specialists to develop exercises, and providing faculty with time for curriculum and professional development. While sound and well aimed, these suggestions would be difficult for individual faculty members to tackle on their own, especially without departmental support or in departments that lack proper institutional (financial/grant) support. A different approach to lowering the barriers to implementation involves creating a framework that would allow a large number of research questions to be easily adapted for use in CUREs, with the specific goal of being able to use existing research projects on a large scale and in lower-division courses. Ideally, this framework would also provide practical advice on how CUREs can be scaled up to involve larger class sizes and/or greater numbers of sections.

The Introductory Biology Program in the Department of Biological Sciences at Louisiana State University (LSU) has implemented CUREs in freshman biology labs for majors (BIOL 1207/ 1208 and BIOL 1209/1503 [1207 and 1503 are the honors versions of 1208 and 1209, respectively]) over four semesters during the past three years, serving as many as ten 30-student sections per semester, and performing research on six different projects. These projects have ranged from bench-based molecular biology experiments to behavioral studies to greenhouse and field-based ecology projects. Based on these experiences, here we present a general framework we have created for designing and implementing a CURE using ongoing research projects pursued by faculty members within the department. We also provide support materials, including course activities and grading rubrics, as online supplemental files that can be modified to suit a broad range of course types and research questions. Finally, we provide some advice and thoughts to consider when choosing CURE projects and teaching assistants, in hopes that our experiences and materials will aid other institutions in implementing CUREs on a larger scale.

\section{O Implementing Highly Scalable CUREs in Freshman Biology Labs}

\section{Course Context}

We implemented our CUREs in BIOL 1207/1208 and BIOL 1209/ 1503 lab courses. These labs are designed for freshman biology/science majors. The traditional BIOL 1207/1208 course covers basic lab techniques such as pipetting and spectrophotometry, enzyme activity, carbon metabolism, and molecular biology, while the traditional BIOL 1209/1503 lab covers systematics, evolution, ecology, and diversity. They consist of one three-hour lab meeting per week. Each lab section is taught by a graduate teaching assistant (TA) and consists of $\leq 30$ undergraduate students, with each TA typically teaching two lab sections per semester. There are as many as 54 sections of each course taught each semester. The "honors" sections, BIOL 1207 and 1503, generally cover the same topics but have a greater emphasis on experimental design and written communication.

CUREs were implemented in all of these courses, with the appropriate choice of course being determined by the subject of the research. Selection of CURE research topics is discussed below. Up to 10 sections of BIOL 1208/1207 or 1209/1503 were designated as CUREs in a given semester. The sections chosen to be CUREs depended on the availability of the TAs chosen to teach them. Details about TA selection and training are provided in the Discussion.

\section{CURE Framework}

To reduce the amount of time necessary to plan so many different CUREs, we have developed a general framework (Table 1), a course schedule for 13 weeks that has helped us streamline the process. In general, our CURE schedule starts by introducing students to the study system, with an emphasis on learning how to comprehend primary literature. Based on an in-class workshop designed to introduce freshmen to scientific papers, students read at least two papers a semester and present one of their choice toward the end of the semester. For each semester of CURE, we plan for one or two experiments that span multiple weeks interleaved by classes on data analysis, including basic statistical analysis (if appropriate) and data interpretation.

Student assessment is built into the schedule in the form of quizzes and formal and informal written assignments, which require students not only to master the basic scientific knowledge pertaining to the project, but also to be proficient in data analysis and interpretation. They must also be able to skillfully communicate their findings in writing as well as orally during a poster presentation in class. Student training in both scientific writing and poster development are built into the schedule at appropriate times, based on the project (Table 1). To better prepare students for designing their own posters, they critique several existing posters and also provide feedback on rough drafts of posters designed by other groups within the section. The semester culminates in the students' work being showcased through a public poster display.

The level of flexibility built into the framework schedule makes it is easily customizable to different projects. Importantly, not all aspects of the framework need to be implemented in any given semester. For instance, the statistics portion of the framework may not be necessary, given the research project at hand, and may be excluded if inappropriate. Similarly, the individual-choice scientific paper presentations are optional activities and may be skipped to make room for "make-up" classes required in the event of failed experiments. In order to better demonstrate how we implemented this framework across various semesters, we have outlined week-by-week activities performed for two very different CURE projects (Supplemental Material Table S1).

\section{CURE Course Materials \& Rubrics}

The CUREs implemented in the Freshman Biology laboratories at LSU focus on deepening the students' understanding of the scientific process, with an emphasis on reading and understanding primary scientific literature, data analysis and interpretation, and effective communication of scientific data through written reports and poster presentations, regardless of the specifics of the research project. To that effect, we have made the following CURE course materials and rubrics available as supplemental materials:

- Course Outline Flowcharts: Diagrammatic representation of the scientific process that the CURE is intended to guide the students through (Figure 1). Students are expected to complete the flowchart with the specifics of the research project they are participating in, with the help of the TA. This flowchart also aids the PI, whose project is being used, in planning and structuring the CURE. The portion of the flowchart bracketed in Figure 1 
Table 1. Generalized CURE framework with suggested activities, relevant assignments and supporting documents. Each topic spanning multiple weeks has been color-coded below to assist the reader in assessing the flexibility of this framework as applied to two very different projects, as shown in Supplemental Material Table S1.

\begin{tabular}{|c|c|c|c|c|c|c|}
\hline Week & Topic & Quiz & Quiz Topic & $\begin{array}{c}\text { In-Class (Group) } \\
\text { Activity }\end{array}$ & $\begin{array}{c}\text { Assignments, Exams, } \\
\text { Reminders }\end{array}$ & $\begin{array}{l}\text { Supporting } \\
\text { Documents }\end{array}$ \\
\hline 1 & $\begin{array}{l}\text { Background, } \\
\text { how to read } \\
\text { research paper }\end{array}$ & & & $\begin{array}{l}\text { What types of } \\
\text { information would } \\
\text { be found in which } \\
\text { major sections of a } \\
\text { paper? }\end{array}$ & $\begin{array}{l}\text { HW based on } \\
\text { research paper (no. 1) } \\
\text { assigned }^{\text {a }}\end{array}$ & $\begin{array}{l}\text { How to Read } \\
\text { Scientific Literature }\end{array}$ \\
\hline 2 & $\begin{array}{l}\text { Interactive } \\
\text { paper } \\
\text { discussion, } \\
\text { experimental } \\
\text { design }\end{array}$ & 1 & $\begin{array}{l}\text { Background } \\
\text { and research } \\
\text { paper - after } \\
\text { discussion }\end{array}$ & $\begin{array}{l}\text { Create/complete a } \\
\text { diagrammatic } \\
\text { flowchart based on } \\
\text { experimental } \\
\text { outline for the } \\
\text { semester }\end{array}$ & $\begin{array}{l}\text { HW based on } \\
\text { research paper (no. 1) } \\
\text { due }\end{array}$ & $\begin{array}{l}\text { Course Outline } \\
\text { Flowcharts }\end{array}$ \\
\hline 3 & $\begin{array}{l}\text { Project part I - } \\
\text { theory lecture }\end{array}$ & & & $\begin{array}{l}\text { Perform project } \\
\text { part I }\end{array}$ & $\begin{array}{l}\text { Research sources of } \\
\text { primary literature for } \\
\text { referencing; review } \\
\text { non-exercise slides } \\
\text { from Scientific } \\
\text { Writing as HW }\end{array}$ & Scientific Writing \\
\hline 4 & $\begin{array}{l}\text { Project part I } \\
\text { continued.; } \\
\text { discussion on } \\
\text { Scientific } \\
\text { Writing }\end{array}$ & 2 & $\begin{array}{l}\text { Theory } \\
\text { behind part I }\end{array}$ & $\begin{array}{l}\text { Obtain and/or } \\
\text { analyze results }\end{array}$ & $\begin{array}{l}\text { Informal (in-class) } \\
\text { writing I; Formal } \\
\text { Writing I assigned }\end{array}$ & $\begin{array}{l}\text { Formal Writing Rubric } \\
\text { and Scientific Writing }\end{array}$ \\
\hline 5 & $\begin{array}{l}\text { Project part II - } \\
\text { theory lecture }\end{array}$ & 3 & $\begin{array}{l}\text { Results } \\
\text { interpretation } \\
\text { from part I }\end{array}$ & $\begin{array}{l}\text { Perform project } \\
\text { part II }\end{array}$ & $\begin{array}{l}\text { Informal writing I } \\
\text { returned }\end{array}$ & \\
\hline 6 & $\begin{array}{l}\text { Project part II } \\
\text { continued }\end{array}$ & 4 & $\begin{array}{l}\text { Theory } \\
\text { behind part II }\end{array}$ & Continue part II & $\begin{array}{l}\text { Formal Writing I due; } \\
\text { Formal Writing II } \\
\text { assigned; Find at least } \\
\text { one primary source of } \\
\text { reference for Formal } \\
\text { Writing II and use for } \\
\text { later presentation }\end{array}$ & Formal Writing Rubric \\
\hline 7 & $\begin{array}{l}\text { Project part II } \\
\text { continued; } \\
\text { lecture on } \\
\text { graphing and } \\
\text { statistics }\end{array}$ & & & $\begin{array}{l}\text { Results analysis - } \\
\text { create graphs/ } \\
\text { charts/perform } \\
\text { statistics }\end{array}$ & $\begin{array}{l}\text { Informal (in-class) } \\
\text { Writing II }\end{array}$ & $\begin{array}{l}\text { Introduction to } \\
\text { Statistics and Data } \\
\text { Presentation }\end{array}$ \\
\hline 8 & $\begin{array}{l}\text { Individual- } \\
\text { choice research } \\
\text { paper } \\
\text { presentations }\end{array}$ & 5 & $\begin{array}{l}\text { Results } \\
\text { interpretation } \\
\text { from part II }\end{array}$ & $\begin{array}{l}\text { Research paper } \\
\text { (no. 2) presentation } \\
\text { - day } 1\end{array}$ & $\begin{array}{l}\text { Formal Writing I } \\
\text { returned; Informal } \\
\text { Writing II returned }\end{array}$ & \\
\hline 9 & $\begin{array}{l}\text { Elements of } \\
\text { poster design - } \\
\text { lecture }\end{array}$ & & & $\begin{array}{l}\text { Research paper } \\
\text { (no. 2) presentation } \\
\text { - day } 2\end{array}$ & $\begin{array}{l}\text { Formal Writing II due; } \\
\text { HW on Poster } \\
\text { Critique assigned }^{c}\end{array}$ & $\begin{array}{l}\text { Poster Rubric, Poster } \\
\text { Critique Forms }\end{array}$ \\
\hline
\end{tabular}


Table 1. Continued

\begin{tabular}{|c|c|c|c|c|c|c|}
\hline Week & Topic & Quiz & Quiz Topic & $\begin{array}{l}\text { In-Class (Group) } \\
\text { Activity }\end{array}$ & $\begin{array}{c}\text { Assignments, Exams, } \\
\text { Reminders }\end{array}$ & $\begin{array}{l}\text { Supporting } \\
\text { Documents }\end{array}$ \\
\hline 10 & $\begin{array}{l}\text { Poster } \\
\text { development } \\
\text { and critique }\end{array}$ & 6 & $\begin{array}{l}\text { Elements of } \\
\text { poster design }\end{array}$ & $\begin{array}{l}\text { Informal peer- } \\
\text { critique of poster } \\
\text { drafts }\end{array}$ & $\begin{array}{l}\text { Poster Critique } \\
\text { assignment due }\end{array}$ & \\
\hline 11 & $\begin{array}{l}\text { Final exam and } \\
\text { poster review }\end{array}$ & & & $\begin{array}{l}\text { Interactive review } \\
\text { session; one-on-one } \\
\text { poster help (with } \\
\text { TA) }\end{array}$ & $\begin{array}{l}\text { Formal Writing II } \\
\text { returned }\end{array}$ & \\
\hline 12 & \multicolumn{5}{|c|}{ Poster presentations } & Peer-evaluation forms \\
\hline 13 & \multicolumn{6}{|c|}{ Final exam } \\
\hline
\end{tabular}

Abbreviations: HW = homework; TA = graduate teaching assistant.

${ }^{a}$ Basic questions to engage students in background information and the major take-home points from the research article.

${ }^{b}$ Students must search for relevant research articles (primary literature) to reference information in Formal Writing II. Each group must then choose any one of those papers and present the major elements (background, methods, results, and conclusions) on week 9 or 10.

${ }^{c}$ Evaluate publicly displayed posters within the department for clarity and style; designed to familiarize students with various poster designs.

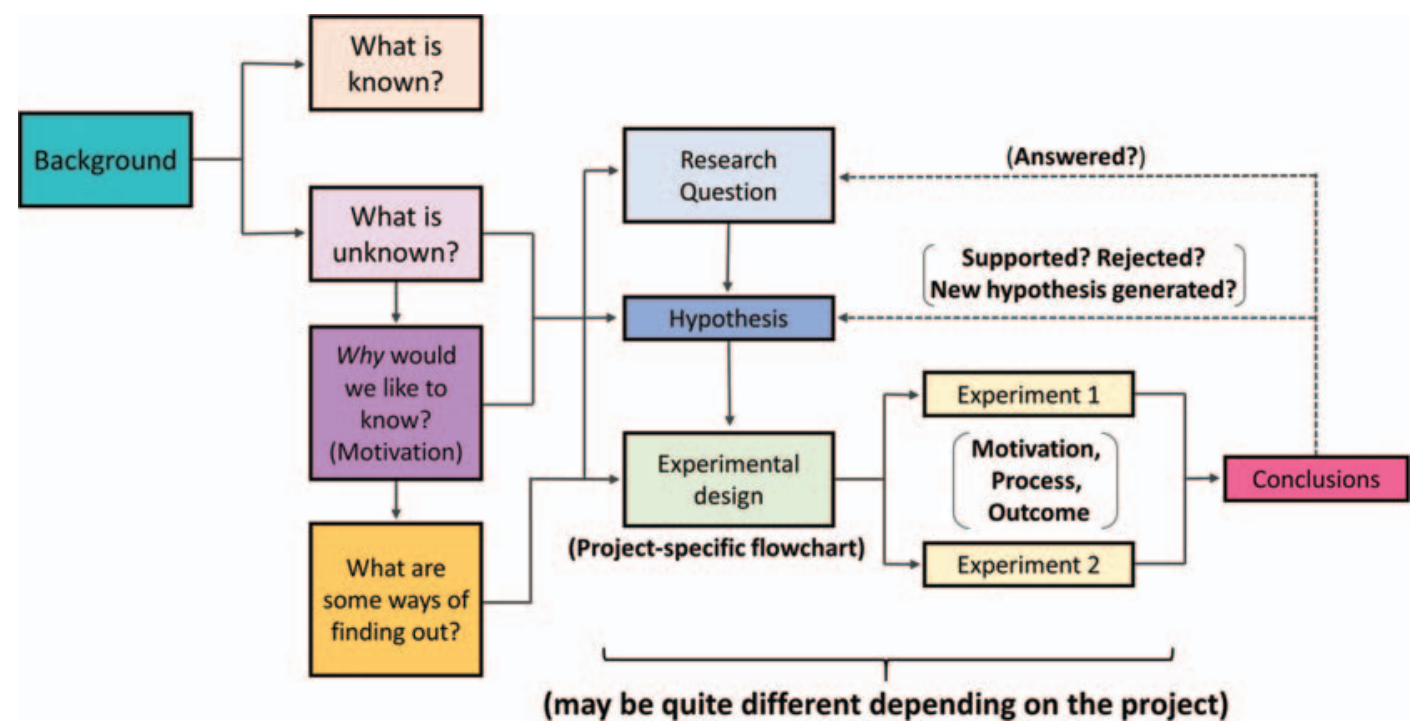

Figure 1. Course Outline Flowchart representing the scientific process that the CURE is intended to guide the students through. The basic components of the flowchart have been color-coded above to assist the reader in assessing the flexibility of this flowchart as applied to two very different projects (Supplemental Materials Figures S1 and S2).

has the potential to be vastly different in terms of organization and presentation, depending on the project. Supplemental Material Figures S1 and S2 demonstrate this level of difference in the experimental segment of the flowchart, as applied to the CURE projects in fall 2014 and spring 2015.

- How to Read Scientific Literature: PowerPoint file designed to be an in-class workshop aimed at familiarizing students with the basic style of scientific manuscripts and tips on how to decode the jargon and extract the main conclusions from a paper (Supplemental Material Appendix 1).

- Scientific Writing: PowerPoint file designed to serve as a training workshop in scientific writing and data presentation for freshman undergraduates (Supplemental Material Appendix 2). We recommend a scaffolded approach to writing scientific papers (Holstein et al., 2015) and providing the students with detailed guidelines for what to include in each section of the paper, based on the specific project being implemented.

- Intro to Statistics: PowerPoint-based lecture on basic statistics in four main parts: (1) understanding the basic need for statistics, (2) creating appropriate statistical hypotheses for the research question, (3) determining the appropriate statistical test based on whether the independent and dependent variables are categorical or numerical, and (4) interpreting and presenting the results in a graphical form. The three main statistical tests discussed here are t-test, analysis of variance, and linear regression (Supplemental Material Appendix 3). This presentation is the product of a collaborative effort among Dr. J. Sebastián Tello, Dr. Barry Aronhime, Warwick Allen, and A.B., and is used with their permission. 
- Grading Rubrics: We provide two main rubrics with this report, the first for the formal writing assignments (Supplemental Material Appendix 4) and the second for the poster presentations (Supplemental Material Appendix 5).

- Poster Critique: In order to better familiarize students with how finished posters should look, we assigned them to critique posters by various research groups displayed within the department. The critique form that the students must complete for this assignment is included as Supplemental Material Appendix 6.

- Peer Evaluation: On the last day of class, students were asked to complete the form presented in Supplemental Material Appendix 7. The peer evaluation served a dual purpose. First, it ensured equal contribution of all team members toward the group project, which received a group grade. Second, it provided an independent assessment of each poster presentation, thus assisting the TA in appropriate grading.

- Designing Scientific Posters: PowerPoint file (Supplemental Material Appendix 8) designed to introduce students to designing scientific posters, with several guidelines regarding section content, use of colors and fonts, example posters, and activity question to help students start developing their own posters. This presentation was created by Dr. Becky Carmichael and edited by A.B., and is used with their permission.

\section{O Implementation at LSU}

Nationally, CUREs have included projects designed and implemented at the university but not tied to a faculty member's research (e.g., Brownell et al., 2015; Russell et al., 2015), while others have found great success implementing portions of their own research projects (e.g., Miller et al., 2013; Venesky, 2015). We have focused our CUREs solely on implementing portions of ongoing, in-house research projects, for reasons outlined in the Discussion. We recruited faculty and graduate student projects by word of mouth and by sending emails to the department asking faculty if they had research that they felt was amenable to a CURE. We then worked with the researchers to identify the elements of their research that met the following criteria:

- The research performed by the undergraduates would be directly related to an ongoing research project and make a meaningful contribution to the PI's research.

- The project or experiment consisted of several treatments or replicates, allowing each student group to work on a novel portion of the project

- The research protocol could be broken into several subtasks, each of which could be accomplished during a three-hour weekly lab, and/or the delay between subtasks could be at least one week (e.g., setting up and running a polymerase chain reaction $[P C R]$ one week, then running a gel and purifying the product the next week).

- The students could easily be trained to complete the required techniques.

- The samples used in the CUREs were not irreplaceable, and there was enough to replicate the experiment in at least two lab sections. This last criterion is crucial for comparing results across lab sections, allowing for a level of quality control to ensure that the resulting data will be useful to the PI.

The following projects have been successfully implemented as CUREs at LSU:

- CCM Gateway Entry Vector Development in Chlamydomonas reinhardtii (PI: Dr. James Moroney): BIOL 1207, fall 2011, two sections, 43 students. One goal of this research group is to characterize the $\mathrm{CO}_{2}$ concentrating mechanism (CCM) present in the eukaryotic green alga C. reinhardtii. The research involved students cloning selected genes into a Gateway entry vector. Students were given a partial sequence of the gene and were instructed to match that sequence to the C. reinhardtii genome. The partial sequences were supplied by Dr. Moroney's laboratory. Once the students found the gene of interest on the C. reinhardtii genome website, they designed primers and used PCR to amplify their gene and finally put it into a Gateway entry vector. The students had a total of 12 genes of interest and were successful in cloning all 12 genes into gateway vectors. Once a gene has been placed into a Gateway entry vector, that gene can then be put into a variety of destination vectors for expression studies, protein-protein interaction, or localization studies. This provides a very useful set of tools for future work.

- Effects of the BP Oil Spill on Gulf Killifish Embryos (PIs: Dr. Ben Dubansky and Dr. Fernando Galvez): BIOL 1208, spring 2011, two sections, 51 students. The goal of this research was to investigate the long-term impact of the BP Deepwater Horizon oil spill on fish populations. The students assessed the development of Gulf killifish embryos that were exposed to sediment that had received various levels of oil from the BP oil spill. Students measured hatching rate, embryonic heart rate, and mortality. The results of this research were included in Dr. Dubansky's dissertation (Dubansky, 2013) and were recently published in a peerreviewed journal (Dubansky et al., 2013).

- Controlling Ribosomal Genes in Saccharomyces cerevisiae Using the Gall Promoter System (PI: Dr. Raphyel Rosby): BIOL 1207 and BIOL 1208, fall 2014, eight sections, 199 students (Supplemental Materials Figure S2 and Table S1). Students generated a total of 17 mutant strains of yeast (S. cerevisiae) in which the activity of precisely one ribosomal gene was disrupted by the addition of the Gall promoter. This was accomplished by transforming a linear piece of DNA containing the Gall promoter and homology hooks to the targeted gene, isolated from a plasmid using PCR and subsequent ethanol precipitation. The targeted mutations were confirmed by colony PCR and growth assays. Each mutant strain was generated at least in duplicates by groups of three or four students in one to three sections. The generated strains are currently being used by Dr. Rosby to elucidate the signaling mechanisms involved in aberrant ribosome biogenesis that can lead to various disease conditions (ribosomopathies) in humans.

- Interplay of Genetics and Reproductive Behavior in an African Cichlid, Astatotilapia burtoni (PIs: Danielle Porter and Dr. Karen Maruska): BIOL 1207, fall 2014, two sections, 47 students. Students studied and scored videos of male reproductive and territorial behaviors to quantify male dominance. 
They also extracted RNA and produced cDNA from tissues of female fish to investigate the expression of several genes related to feeding behaviors and reproductive state. These data were used in Ms. Porter's thesis (Porter, 2015) and provided Dr. Maruska with pilot data for future studies.

- Evolutionary Tradeoffs between Thermal and Salinity Tolerance in Copepods (Tigriopus californicus) (PI: Dr. Morgan Kelly): BIOL 1209, spring 2015, two sections, 54 students. Students measured thermal and salinity tolerance of tide pool copepod ( $T$. californicus) lines. These lines were selected for varying levels of tolerance to heat or salinity over 10 generations. Each group of two to four students in a lab section exposed one or two lines of copepods to varying salinities and temperatures and measured copepod survival. All copepod lines were measured in each section and replicated between sections. Students participated in a single-blind study (they did not know which lines they were testing until the end of the project) to minimize bias. These data are being added to a larger dataset for eventual publication. This project was continued in spring 2016.

- Competitive Ability of Invasive Elephant Ear (Colocasia spp.) against Native Plants (PI: Dr. Barry Aronhime): BIOL 1503, spring 2015, two sections, 48 students (Supplemental Materials Figure S1 and Table S1). Students investigated the ability of elephant ear (Colocasia spp.), an invasive plant, to outcompete native species in greenhouse and field experiments. In the greenhouse, each group of two to four students set up experiments in which elephant ear was potted with a different native plant and measured plant traits associated with competition throughout the semester, with the experiments being replicated across two sections. They also measured elephant ear and native plant growth in a natural field setting (Bluebonnet Swamp in Baton Rouge, Louisiana) at the beginning and end of the semester. These data are being added to a larger dataset for eventual publication. This project continued in fall 2015 and spring 2016.

\section{Discussion}

In recent years, the approach to science education has developed rapidly toward involving more undergraduates in research as a way to improve their scientific literacy in either traditional URE, SURE, or CURE opportunities (Linn et al., 2015). CUREs have an added advantage over SUREs in that they are able to involve a larger number of students, especially those in the lower divisions (Linn et al., 2015). Most importantly, through CUREs, students get a taste of how laboratory science actually works, which they are often unable to glean from traditional "cookbook" labs. By intentionally choosing projects whose outcomes were unknown and could very possibly fail - and in every case, some aspect of the project did - we engaged our students in the troubleshooting process that is integral to being able to do science. This gave the students invaluable insight into the fact that science is not a linear process: it proceeds in fits and starts, and in some cases must backtrack, before having the necessary data to answer the question at hand.

However, despite the myriad advantages of CUREs, large-scale implementation has so far been limited in undergraduate laboratories, mainly because of limited time for faculty to develop research experiences, the cost of implementation, class size, and the available number of sections (Spell et al., 2014). Thus far, we have supplied a framework and supplemental materials addressing several of these barriers; below, we provide some general advice, based on our experience, to help other institutions implement CUREs on a similarly large scale.

\section{Benefits to Using Ongoing, In-House Research}

Using in-house research projects greatly enhanced our ability to provide CUREs by assisting with many of the logistical considerations necessary to run a classroom laboratory. First, since these projects are part of the faculty's ongoing research, the faculty are not spending additional time developing research experiences, thus eliminating the most important barrier according to Spell et al. (2014). Second, when considering in-house projects, at least at a research university, CURE facilitators are not limited by the number of available projects and may select those most amenable to CUREs. By choosing projects that involve multiple treatments or replicates, we have been able to expand the number of sections involved in any one project to 8-10 sections when utilizing multiple projects per semester, allowing us to incorporate them into large-enrollment courses. Third, teaming with resident PIs to scale up existing projects has been advantageous because we were privy to their expert advice and assistance in troubleshooting the inevitable problems that arose during the course of a semester. While there are still costs of materials and supplies, we have been able to defray some of the expenses for these freshman labs by utilizing materials and supplies from the associated research lab, which also provided logistical assistance and TA training.

Although the monetary costs to the PIs have thus far been minimal, financial considerations are important for the continued sustainability of CUREs here and elsewhere. Several PIs here at LSU are taking CUREs into consideration when applying for research funding by including samples, reagents, and other consumables for CUREs in their budgets. Their motivation to do so stems from the fact that PIs have benefited from CUREs by having many, albeit unskilled, hands collecting usable data for them at a relatively low cost. Data collected by CURE students have been incorporated into at least one publication (Dubansky et al., 2013), two dissertations/ theses (Dubansky, 2013; Porter, 2015), and several grant applications. This gives the PIs a vested interest in the outcome of the lab and can be viewed favorably in the "Broader Impacts" statements required in many grant applications. From a CURE perspective, this reduces the need to continually recruit new projects each semester (we have two or three projects that are currently ongoing), and the continuity helps streamline the presemester preparations for the PI as well as the lab prep staff.

Among other benefits, using in-house research allowed students to see and be a part of real, cutting-edge research, thus developing a connection with the department that they might not otherwise make. Students often report feeling alienated by faculty who they perceive as being only interested in research (Miller \& Metz, 2014). CUREs with research from our department have provided our students an introduction to the ongoing research activity conducted by their current or future professors and have been stepping-stones for lower-division students to gain easy access to research laboratories. Student workers are often involved in the research labs from which CURE projects have originated and have, in several cases, been recruited by PIs because of their involvement in the CUREs - a trend that, we suspect, will continue in the future. 


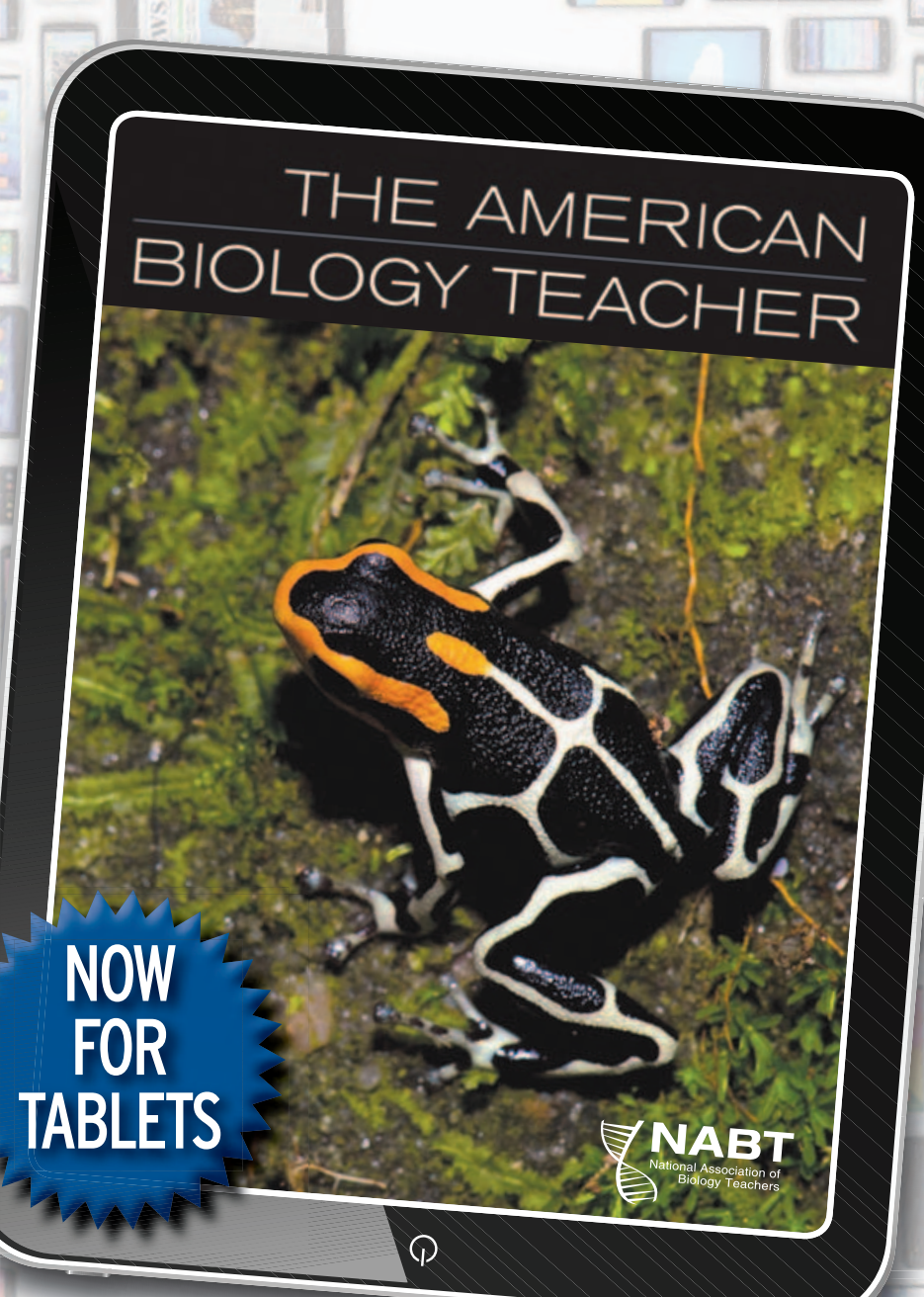

\section{Get your favorite biology education resource delivered your favorite way.}

\section{The American Biology Teacher} is now available on your digital devices.

\section{Visit www.NABT.org/publications \\ for more information, or find the $A B T$ on iTunes, Google Play, and Amazon.}

\section{Cinpsoter}

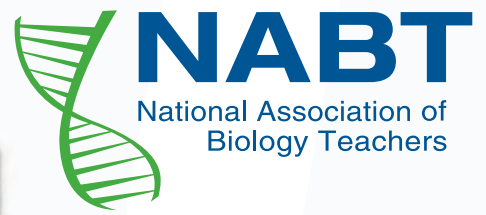

\section{TA Selection \& Training}

TAs teaching CUREs can be confronted with challenges that are quite different from those typically faced when teaching cookbook labs, so care must be taken when choosing and training TAs to teach CUREs. We make the following recommendations, based on our experience.

First, whenever possible, we have chosen TAs working in the research lab from which the CURE project originated. This has worked very well for all parties involved and has resulted in some TAs incorporating data obtained by the CURE in their thesis or dissertation (Dubansky, 2013; Porter, 2015). In cases where the TAs were not from the PI's lab, we chose TAs who had general knowledge of the research and approaches, had several semesters of prior teaching experience, and had set themselves apart from other TAs by their maturity and problem-solving ability.

Second, TAs should be provided with training and encouragement to step away from the traditional teacher/lecturer role they often play in typical labs and into the role of a guide or mentor to help students learn by discovery. In that respect, they should be primed with strategies to encourage students when their experiments fail and use these as teachable moments by pointing out that failure is a part of science. Because often the TAs' own experiments have failed (or are failing), they can be particularly empathetic toward their students' feelings after failure, and perhaps share with them strategies the TAs themselves use to move past failures. The majority of this training took place during weekly lab-prep meetings. Details on these training sessions will be discussed in more detail in a forthcoming publication.

Third, TAs selected to teach CUREs must be able to communicate scientific details in a simplified form. Since incoming freshmen cannot be expected to know scientific jargon, TAs must be able to disseminate the necessary information in laymen's terms for optimum student understanding and participation. Ideally, they should be comfortable with making analogies and designing active-learning exercises to make the scientific ideas and terminology more relatable for the students, thus engaging them more deeply and allowing them to feel a sense of ownership of the project. Suggestions for training TAs to do this will also be discussed in the forthcoming publication mentioned above

\section{Conclusions}

Though an excellent approach for introducing undergraduates to research and the process of science, CUREs can be challenging to implement on a large scale. We feel that the framework and course material we have presented here will be a useful tool for others when designing CUREs at their home institution. In addition, we hope that our advice, gleaned from implementing a variety of CUREs for a large number of students, will also be helpful when planning CUREs.

\section{Acknowledgments}

We thank the following PIs and TAs for their help in providing research projects and implementing the CUREs (in alphabetical order): Warwick Allen, Dr. Barry Aronhime, Jasmine Brown, Apurva Bocar, Dr. Shawn Doyle, Dr. Ben Dubansky, Dr. Fernando Galvez, Katherine Hovanes, Dr. Morgan Kelly, Dr. Yunbing Ma, Dr. Karen Maruska, Dr. Jim Moroney, Dr. Bratati Mukherjee, Danielle Porter, and Dr. Raphyel Rosby. Ann Jolissaint and Dr. Jane 
Reiland provided immeasurable logistical help in setting up the CUREs and keeping them running smoothly. Dr. Becky Carmichael is generously thanked for allowing us to use her presentation on how to design scientific posters. We also extend our gratitude to Dr. J. Sebastián Tello, Dr. Barry Aronhime, and Warwick Allen for allowing us to use and modify their presentation on Introduction to Statistics. Dr. Eve McCulloch provided very helpful comments on an early version of the manuscript. Finally, we wish to thank the many undergraduate students who have taken the CUREs and provided us with valuable feedback.

\section{References}

AAAS (2011). Vision and Change in Underóraduate Bioloģy Education: A Call to Action. Washinģton, DC: AAAS.

Brownell, S.E., Hekmat-Scafe, D.S., Singla, V., Seawell, P.C., Imam, J.F.C., Eddy, S.L. et al. (2015). A high-enrollment course-based undergraduate research experience improves student conceptions of scientific thinking and ability to interpret data. CBE Life Sciences Education, 14(2), ar21.

Brownell, S.E., Kloser, M.J., Fukami, T. \& Shavelson, R. (2012). Underograduate biology lab courses: comparing the impact of traditionally based "cookbook" and authentic research-based courses on student lab experiences. Journal of College Science Teaching, 41(4), 36-45.

Dubansky, B.D. (2013). The effects of natural and anthropogenic stressors on the stress response and tissue-level response in teleost fish. Ph.D. dissertation, Louisiana State University.

Dubansky, B.D., Whitehead, A., Miller, J.T., Rice, C.D. \& Galvez, F. (2013). Multitissue molecular, genomic, and developmental effects of the Deepwater Horizon oil spill on resident gulf killifish (Fundulus grandis). Environmental Science \& Technoloǵy, 47, 5074-5082.

Graham, M.J., Frederick, J., Byars-Winston, A., Hunter, A.-B. \& Handelsman, J. (2013). Increasing persistence of college students in STEM. Science, 341, 1455-1456.

Holstein, S.E., Mickley Steinmetz, K.R. \& Miles, J.D. (2015). Teaching science writing in an introductory lab course. Journal of Undergraduate Neuroscience Education, 13, A101-A109.
Lei, S.A. \& Chuangु, N.-K. (2009). Undergraduate research assistantship: a comparison of benefits and costs from faculty and students' perspectives. Education, 130, 232-240.

Linn, M.C., Palmer, E., Baranger, A., Gerard, E. \& Stone, E. (2015). Undergraduate research experiences: impacts and opportunities. Science, 347, 1261757.

Lopatto, D. (2004). Survey of Undergraduate Research Experiences (SURE): first findings. Cell Biology Education, 3, 270-277.

Lopatto, D. (2007). Underograduate research experiences support science career decisions and active learning. CBE Life Sciences Education, 6, 297-306.

Miller, C.J. \& Metz, M.J. (2014). A comparison of professional-level faculty and student perceptions of active learning: its current use, effectiveness, and barriers. Advances in Physiology Education, 38, 246-252.

Miller, C.W., Hamel, J., Holmes, K.D., Helmey-Hartman, W.L. \& Lopatto, D. (2013). Extending your research team: learning benefits when a laboratory partners with a classroom. BioScience, 63, 754-762.

Porter, D.T. (2015). Distribution and female reproductive state differences in orexigenic and anorexigenic neurons in the brain of the mouthbrooding African cichlid fish, Astatotilapia burtoni. M.S. thesis, Louisiana State University.

Russell, J.E., D'Costa, A.R., Runck, C., Barnes, D.W., Barrera, A.L., HurstKennedy, J. \& others. (2015). Bridģing the underograduate curriculum using an integrated course-embedded undergraduate research experience (ICURE). CBE Life Sciences Education, 14(1), ar4.

Spell, R.M., Guinan, J.A., Miller, K.R. \& Beck, C.W. (2014). Redefining authentic research experiences in introductory biology laboratories and barriers to their implementation. CBE Life Sciences Education, 13, 102-110.

Venesky, M. (2015). Guidelines for class projects as publishable research. Liberal Arts Ecologists. Available online at https:// theliberalartsecologists.wordpress.com/2015/05/14/guidelines-forclass-projects-as-publishable-research/2015.

ARUNDHATI BAKSHI (abakshl@Isu.edu), LORELEI E. PATRICK, (loreleipatrick@gmail.com), and E.WILLIAM WISCHUSEN (ewischu@lsu.edu) are all in the Department of Biological Sciences, Louisiana State University, Baton Rougge, LA 70803 Arundhati Bakshi and Lorelei, E. Patrick contributed equally to this work.



